\title{
The Effect of Language and Context Variability on the Translation of Literary Postcolonial Discourse in Portuguese*
}

\author{
Rebeca Hernández \\ Universidad de Salamanca
}

\begin{abstract}
This paper attempts to address questions related to the translation of postcolonial literary discourse in Portuguese, its meta-communicative functions and the capacity which translators have to occupy different ideological positions during the process of translation. Here, the choice of position is first related to the cognitive space which works as the referential locus for the representation of content and context through language. Secondly, it is presented as governed by variations in the principle of relevance, which may be to the source community, to the target audience, or doubly oriented. The paper argues that the way in which translators deal with the language and context of the text (by using plurilingualism vs. monolingualism, or by preserving or not cultural specifics) influences the reader's mental reconstruction of the world represented in the original. The analysis of the translator's choices also helps to define his/her position as discourse interpreter, cultural negotiator, and his/her degree of implication in the recreation of the textual reality. To explore these issues, we will consider three cases of translations into English of postcolonial plurilingual literary texts in Portuguese, all of them
\end{abstract}

\footnotetext{
* Research for this article has been financed by the Junta de Castilla y León grant SA012A09
} 
presenting the typical characteristics of linguistic and cultural hybridity.

Keywords: translation, postcolonial literature, ideology, context of production, context of reception, mental models

\section{Theoretical Background: Translation, Ideology and Mental Model Construction}

In her article "Ideology and the position of the translator. In What Sense is a Translator 'In Between'?," Maria Tymoczko discusses the conceptualization of translation as a cultural and ideological "in between" metaphorical space from a wide range of perspectives. At the core of her argumentation are Bhabha's and Spivak's influential thesis that the inter-languages, inter-nations space of multicultural peoples constitutes a distinct space for ideological translation. From a content/context pragmatic approach, Tymoczko points out that both the source and target texts are mutually independent speech acts with not necessarily coincident locutionary, illocutionary and perlocutionary forces. She contends that preserving and/or transmitting the ideology of the source text through translation involves not only the representation of the original text content and context but also the translator's interpretation, decisions, and goals, whose relevance may be determined by the beliefs and expectations of his/her context of reception. Tymoczko examines in detail the extended practice of conceptualizing translation in terms of a spatial metaphor, and traces the origins of this practice through etymological analyses, as well as through philosophical, historical and physical reasons which present the translator as mediator between cultures, occupying a middle position during the act of communication. She also evaluates the "in between" mode of translation as poststructuralism's response to structuralism's binary way of thinking, as a way to counteract the effects of polar opposites and to promote viewing translation as a 
process connecting languages and cultures with no predetermined source and target positions for ideologies, attitudes or values. Tymoczko questions this formulation on linguistic grounds, arguing that "if language is seen as part of a formal system, a code (as it generally has been in modern linguistics), then a spatial concept of translation [...] has very limited utility in translation theory" (195).

Tymoczko gives the translator, however, a "place of enunciation" whose nature, she claims, involves "an ideological positioning as well as a geographical or temporal one" (183). She contemplates other theories like that of Simms, which situate the translator "within the receptor culture" ("the most common case," in her own words), "within the source culture," or even "elsewhere" in a third culture different from the source and target (2003: 184). The triple stand she describes, in combination with her assertion that "a firm cognitive and theoretical foundation makes it more probable that a cultural project will draw together groups of people and inspire them to work in concert" (181), will be used in this paper to attempt an explanation of the translator's capacity to move within and between ideological positions in terms of mental models. To achieve this aim, we will analyse three cases of translations into English of postcolonial plurilingual literary texts in Portuguese, all of them presenting typical cases of linguistic and cultural hybridity. The point will be to focus on the cognitive representation or mental model which translators (as readers of the original text) build while they receive and interpret discourse, a mental model which may lead to choices regarding different ideological stands during the process of recreation through translation.

\subsection{The Theory of Mental Models: Language, Context, Cognition and Relevance}

In his theory of mental models, psycholinguist Johnson-Laird $(1983,1988,1995,2004)$ maintains that discourse comprehension 
does not refer directly to reality but involves the construction by language users of mental models of the situation described in the text as they receive the information. According to Johnson-Laird, the mental models discourse receivers build for the linguistically represented situation interact with other models which they may have formed by other means of perception, memory, or imagination, and are subject to change and manipulation through thinking and reasoning (1988: 115; 2004: 181). He states that "models are the natural way in which the human mind constructs reality, conceives alternatives to it, and searches out the consequences of assumptions" (1995: 999). Johnson-Laird's main claim is that "discourse models are constructed on the basis of inferences from general knowledge and from a specific knowledge of context"; he considers it a mistake "to talk of the context of an utterance" as he maintains that "there is a context for the speaker, and another for the listener" (1983: 386, italics in the original). These assumptions are relevant to the process of translation, for they imply that translators do not only work with language and context but have as a central source of reference the mental representation which they have worked out for the information and the situation depicted in the original. Thus, cognitive inferential work drawn from the text content and the actual and/or evoked text context(s) play a role as essential as the translator's own context and his/her world and linguistic knowledge. Specially important are the strategic dissociation of text and context and the distinction of separate contexts for the producer and the receiver in JohnsonLaird's theory, since both generate a set of context options for the translator to build a space for meaning in his/her varied position of discourse interpreter, cultural negotiator, and re-creator of the textual reality. Equally crucial is the fact that the referential locus for the representation of context is a cognitive space.

Van Dijk also calls attention to the bond between language, context and cognition. He states that "the relationships between discourse and society should be framed within a theory of the role of 
social cognition in processes of social, political and cultural reproduction" (1989: 163). He claims that the mental representations of these contextual processes act as an interface between individual discourse production and reception and the social structures. Thus, knowledge and data emerging from personal beliefs and standpoints contribute to shaping the situation model derived from environmental and spatio-temporal factors, and interact with the existing cognitive material based on shared group conventions and culturally acquired ways of thinking and behaving. In practical terms, this implies that the translator's own model of the world will interrelate with his/her attitude and feelings towards the translated text and its setting, the combination of both playing an active role in the selection not just of language but also of context. And the same may be said of all other participants involved in the translation transaction activity, such as writers, editors and readers. This state of things introduces an array of mental models which may mark the translator's position and condition his/her decisions. Van Dijk says that it is possible for language users (producers and receivers) to construct sub-models for specific aspects of the text and context guided by the principle of relevance (1989: 197).

$\mathrm{Ku}-\mathrm{Mesu}$ (1997) investigates issues of relevance with regard to the comprehension of hybrid texts by readers of Europhone African writers. She describes the interpretive situation as problematic for it usually involves a complex plurilingual text, a far from uniform audience of African readers, and a much larger audience of those who speak the same European language but share neither the African language(s) nor the African context. Ku-Mesu applies Sperber and Wilson's theory of relevance (1986/ 1995), and sets up a relationship between processing effort and contextual and cognitive effects to the comprehension process of Ghanaian readers and nonGhanaian readers of Ghanaian English-language texts. In her analysis, she follows the general assumption that the less processing effort a text requires and the greater the contextual effects it 
produces, the more relevant it is in terms of readability and rewarding interpretation. From this perspective, she considers different strategies of plurilingualism by African writers (such as lexical code-switching, africanization of the language, or transposition of the autochthonous syntactic patterns on the europhone language) and evaluates the cognitive and contextual benefits and mishaps which these uses have on the two types of audiences she is contemplating: the Ghanaian and the non-Ghanaian. Her conclusion points to the convenience of distinguishing two different kinds of relevance, what she calls "mother-tongue relevance" and "othertongue relevance", which is in agreement with Sperber and Wilson's argument that relevance is a function of the individual's cognitive effects and his/her choice of accessible contexts (1986/1995: 136145). Ku-Mesu bases the distinction on the claim that "the audience [whose sociolinguistic context is different from the communicator's] embarks on constructing a context in which the utterance is meaningful to them" (1997:51, italics in the original).

\subsection{Variable Models of Representation of Content and Context}

The construction of a "relevant" context for a given text which may or may not be a part of the reader's experiential frame is a cognitive operation triggered by the reception and interpretation of discourse information and, therefore, connects with the notion of "mental model", understood as a psychological representation of real or imaginary situations, developed by language users as part of their thinking processes. Linking the principle of relevance to the notion of mental model is helpful to analyse the translator's position with respect to hybrid texts for it allows the problem to be formulated in terms of cognition and choice of context. On the one hand, there is the question of whose relevance is primed during the act of translating (in our case, a postcolonial plurilingual literary text in Portuguese into English), because it opens a set of options which 
include at least relevance to the writer, the translator, the editor or the target audience. Another important and related issue is the choice of context which ranges from the writer's hybrid/plurilingual milieu to the audience's monolingual reality, both of them known to the translator, who occupies a middle position between the source and target cultures and can, therefore, opt for a hybrid/plurilingual approach to the translated reality or a strictly monolingual recreation and transfer of the source language(s) and culture system(s) onto the language and culture of reception. In none of these options need language be a barrier for the construction of simple and/or complex mental images triggered and shaped by language-dependent parameters done on the basis of previous knowledge, discourse acquired knowledge, the collective imaginary and/or personal experience, imagination and beliefs. As Garnham emphasizes, in the development of mental models language is "a tool that can be used to convey information about the world, but it does not follow that language itself is the system in which situations in the world are represented" (1987: 16). Garnham specifies that it is people, objects and events, not linguistic structures, that are represented in models obtained from or built through discourse (1987: 135). The mental status thus given to the discourse of translation acts as a unifying base from which to decide on the creation of variable models of representation as regards the language patterns used to convey both content and context.

In the case of hybrid literary texts, in our case in Portuguese, where writers make use of words and structures from different linguistic systems, code-swithching or other similar linguistic techniques as a means to represent actual reality and/or ideological and political stands, the translator has options to go from absolute to partial use of monolingualism or plurilingualism; s/he may also choose to propositionally describe or not language alternations and context specifics, or to accompany the text with explanatory notes or glossaries. In this sense, adopting an intermediate position more or 
less equidistant with respect to the source and target cultures and audiences, means that the translator must open spaces in his/her discourse for issues related with the mental representation of values such as ethics, identity or, in texts produced in a colonial context, resistance. These open spaces may work as an invitation for the target audience to vividly and directly incorporate a part of the other experience into their monolingual and monocultural perspective. In this sense, Tymoczko's warning against "claiming as universal a theoretical assertion that is based on the particularities and histories of a few Western European languages" (192) actually connects with the in-between theoreticians which she discusses in her article.

In the following section, we will investigate the scope and variety of the translator's options and decisions through the analysis of three different cases of translations into English of plurilingual poscolonial literary texts in Portuguese. The first case will explore features of the translation into English of Mozambican writer Mia Couto's collection Cada Homem é uma Raça. The second will analyse the translation of "Rosita até Morrer" a story by Mozambican author Luís Bernardo Honwana. And finally, we will consider the translation of Crónica de Uma Travessia by Timor writer Luís Cardoso. All three offer distinctively separate ways of dealing with the issues of what and how to translate when the language of the original is hybrid and plurilingual.

\section{The Translator's Standpoint: Three Examples of Mental Model Construction and Context Recreation.}

\subsection{Priming the Target Audience's Perspective}

We will consider a selection of cases from the translation into English of Mia Couto's short story collection Cada Homem é uma 
Raça by British translator David Brookshaw. We will also compare some aspects of Brookshaw's translation of the story "A Princessa Russa", included in this collection, with another existing version of the same story that Luís Rafael, a Southafrican translator of Mozambican origin, published in The Picador Book of African Stories. The language and style of Couto's books partake of the plurilingual quality characteristic of postcolonial literary discourse written in the Europhone languages, and does so in a highly personal and creative way. Of a younger generation of writers who have grown up in the hybrid postcolonial society, Couto writes in Portuguese and uses the classic resources of plurilingualism (such as the insertion of autochtonous words and the superimposition of autochtonous syntactic patterns and intonation rhythms on the European language, code-switching, textual glosses providing cultural information, and/ or footnotes or glossaries for the African terms) and combines them with innovative and imaginative linguistic fusions that lead to creative conceptual blends and associations. As he says in an interview with Maria João Avilez, this challenging use of pluri-lingualism and linguistic experimentation are meant to approximate in a more natural and accurate way the cultural and social specificity of Mozambique's African-Portuguese life and way of being (Maciel 2004: 4). Needless to say, the complexity of these linguistic traits turn Couto's texts into a real challenge for the translator, who has to decide what kind of conceptual model to project in the reconstruction of the textual reality, the possibilities ranging between a close-to-the-source-culture model built on linguistic diversity, or a close-to-the-reception-culture model based on primarily monolingual discourse.

In Mia Couto's Portuguese edition of his short story collection Cada Homem é uma Raça, the African reality is present in a variety of linguistic ways. For example, words or expressions from the national languages are introduced in regular font and explained in footnotes the first time they appear in the book, or they are propo- 
sitionally developed in glosses within the text. In some cases, contextualizing paragraphs are also used as a means to incorporate socially or historically relevant information. The following passage from the story entitled "A Princessa Russa" may serve to illustrate how African words are subtly and naturally inserted in his discourse in Portuguese. There are three African terms in the passage "cubata", "xipefo" and "cabedula", the first and the third are defined in footnotes, as can be seen below, while xipefo (in portuguese lamparina) is left unexplained because it has previously appeared in another story in the collection (1990: 56):

(1) Uma noite dessas eu estava na minha cubata ${ }^{1}$, a acender o xipefo. Foi quando uma sombra me assustou á minha trás. Olhei, era a senhora. [...] Fiquei todo atrapalhado, envergonhado até. Sempre ela me via naquela farda branca que eu usava no serviço. Agora, eu estava ali de cabedula ${ }^{2}$, sem camisa nem respeito.

${ }^{1}$ Cubata - pequeno quarto onde eram alojados os empregados domésticos.

${ }^{2}$ Cabedula - calções.

(1990: 80)

Now, in their translations of this passage both Brookshaw and Rafael opt for monolingualism thus introducing no direct link with the African culture in the target audiences' cultural schemata and expectations. This is David Brookshaw's translation:

(2) One of those nights, I was in my hut lighting the spirit lamp. Suddenly, I was startled by a shadow behind me. I looked, and it was the mistress. [...] I stood there tongue tied, ashamed even. She was used to seeing me in the white uniform I wore for work. There I was in my pyjama trousers, devoid of a shirt and of decorum. 
Brookshaw translates cubata as "hut", xipefo as "spirit lamp" and cabedula as "pyjama trousers". Here is Luís Rafael's version of the same passage:

(3) On one of those nights I was lighting the coals in my room at the back. That's when I saw a shadow behind me and got a fright. I looked again and saw that it was Milady. [...] I didn't know what to do. I was even embarrassed. She'd always seen me in the white uniform that I used for work. And here I was in shorts. With no shirt on, with no respect at all.

(2000: 215)

Rafael's and Brookshaw's choices of English terms for the African words in Mia Couto's Portuguese text are different to the point that the mental images they help to create in the receiver's mind are significantly dissimilar: "I was in my hut lighting the spirit lamp" is Brookshaw's version, while Rafael chooses "I was lighting the coals in my room at the back" for the same clause. As for the sentence with cabedula, Brookshaw translates "There I was in my pyjama trousers" and Rafael opts for "And here I was in shorts". In both cases, they produce a monolingual translation which may have the (probably unwanted) side effect of guiding prospective readers into the construction of individual mental models which may miss traces of the original's context and cultural specifics.

In "O apocalipse privado do tio Gueguê", another story from the same collection, Brookshaw chooses to maintain a direct reference to the Mozambican context when he incorporates the African word "capulana" [Mozambican women's colourful wrap/skirt] to his text. In example 4 below, we have Couto's treatment of the word in the original, explained as in the previous case through a footnote; while in (4) Brookshaw keeps the term in his translation but adds no comment or explanation of the word: 
(4) Também eu adormecia quando escutei sombras. Da silhueta saiu uma mulher, capulana ${ }^{1}$ sobre as costas.

${ }^{1}$ Capulana - peça de tecido que as mulheres enrolam à cintura.

I was dozing off too when I heard shadows. A woman emerged from a silhouette, her capulana on her back.

Inserting the African word in the English translation has the immediate effect of instantiating the African frame of reference in the reader's mind, even if the translator, unlike the author, offers no explanation to guarantee that the reader will know the actual nature of the object for which the word stands.

In other cases, when the original gives propositional information of cultural or ethnographic aspects in the form of textual glosses, Brookshaw also oscillates: sometimes he omits the explanation provided, sometimes he keeps it. An example of the first situation is the translation Brookshaw makes of the following passage from the story "A lenda da noiva e do forasteiro." In the Portuguese text the term "amafengu," which designs the survivors of the Abambo tribe, is amply dealt with in a footnote; but the English translation, in (5) below, totally eliminates this piece of information:

(5) Os mais velhos puxavam antigas maldições: nós somos amafengu', o povo esfoemado que procura serviço de viver, pobres que pedem a pobres.

${ }^{1}$ Amafengu: designação que os sobreviventes da tribo abambo davam a si próprios. 'Os Abambo foram uma numerosa e poderosa tribo bantu, do Natal. Foram derrotados e cruelmente perseguidos por outras tribos e tornaram-se errantes, passando a ser conhecidos por Fingos. Procuraram refúgio noutras 
tribos, reduzindo-se ao completo estado de servidão [...] De 250000 restaram alguns 35000 que se dedicaram à agricultura e a criação de gado'. António Cabral, 1975)

The elders hauld out ancient curses: we are the Amafengu, the famished people destined to seek work to live, poor who beg from the poor.

The flexibility of the model allows, however, for different treatments to similar situations. For example, in the story "A Princessa Russa" there is a contextualizing introductory note which reproduces part of a 1946 report by the Portuguese Government:

(6) 'Bastou correr fama que em Manica havia ouro e anunciar-se que para o transportar se construiria uma linha férrea, para logo aparecerem libras, às dezenas de milhar, abrindo lojas, estabelecendo carreiras de navegação a vapor, montando serviços de transportes terrestres, ensaiando indústrias vendendo aguardente, tentando explorar por mil formas não tanto o ouro, como os próprios exploradores do futuro ouro [...]

António Ennes, Moçambique, Relatório Apresentado ao Governo, Lisboa, Agência Geral das Colónias, 1946, pp. 2730 .

(Couto 1990: 75, su cursiva)

In Brookshaw's translation, the note is maintained as follows:

(7) It was enough for the existence of gold in Manica to be rumoured, and for it to be announced that a railway would be built to transport it, for pounds sterling to appear out of the 
blue in their tens of thousands, opening shops, establishing steamship lines, organizing overland transport, investing in industrial enterprises, selling liquor, seeking to exploit in a thousand and one ways not so much the gold, but the very exploiters of the future gold...

António Ennes, Moçambique, Government Report, Lisbon, 1946.

(Couto 1994: 38)

But Rafael, maybe for publishing reasons, drops the quote in his translation and paraphrases it in a note about the author and his work that precedes a brief biographical commentary on the translator. The part of the note that recovers the information from the Government report has been highlighted here in italics:

(8) ["The Russian Princess"] is also in Brookshaw's second collection of Couto stories, Every Man is a Race (1994), also available in the Heinemann African Writers Series. The original story opens with an epigraph from a Portuguese government report of 1946 on the Manica gold fields to the effect that, thanks to wild rumours of a strike, all attempts were being made by entrepreneurs not so much to extract the gold, but to exploit those who came in search of it. This story was shortlisted for The Caine Prize for African Writing 2001. Luís Rafael is a Mozambican-born South African, currently living in Lisbon, who has contributed translations of several Portuguese-language authors from Africa to journals, including an early version of Couto's 'Caramel Rose' to Soho Square (1992).

(Couto 2000: 213)

Variabilities in the treatment of plurilingualism are therefore not constrained to isolated cases. Also in "The Russian Princess", Couto 
uses the African words "moleques" and "mainatos" to refer to house servants and explains the meaning of both words in footnotes to the text (mainatos is not included here as it appeared previously in another story in the book, 1990: 78).

(9) Juntei os moleques ${ }^{1}$, mainatos e também o cozinheiro gordo, o Nelson Máquina.

${ }^{1}$ Moleque: empregado doméstico.

None of the translations into English keep the autochtonous forms this time. Brookshaw translates:

(10) I summoned the houseboys, the servants and also the fat cook, Nelson Máquina.

Rafael, however, selects the phrase "kitchen toto", a term used by white English people in Africa for black servants, to translate mainatos. In this sense he helps to maintain the African component of the story active, but then he eliminates traces of the Portuguese language by translating into English the character's name "Máquina":

(11) I got them all together, the houseboys and the kitchen totos and even the fat cook, Nelson Machine.

(Rafael 2000: 218)

Much of the same happens when the original makes explicit reference to the languages spoken in Mozambique. For example, in the story "O embondeiro que sonhava pássaros" Couto uses the word muska and explains its meaning and origin, the bantú language chissena, in a footnote: 
72 The Effect of Language and Context Variability

(12) O homem puxava de uma muska ${ }^{1}$ e harmonicava sonâmbulas Melodias.

${ }^{1}$ Muska - nome que, em chissena, se dá à gaita-de-beiços. (1990: 63-64, my italics)

In his translation Brookshaw homogenizes the text by translating the word into English and omitting all reference to the bantu language:

(13) The man would take out a mouth organ and put sleepy Melodies to tune.

The result in these types of translation is a rather controlled presence of the African reality in the predominantly English oriented discourse. Thus, readers may construct their personal mental models on the basis of pre-existing cultural schemata and knowledge with few alterations, consequently there is not much need to increment content or context functions. In this way the target audience's processing effort is minimized and therefore relevance to the audience is prioritized.

\subsection{Priming the Hybrid Authorial Perspective}

Luís Bernardo Honwana's short story "Rosita, até morrer" provides a good example of a thoroughly hybrid text as concerns both the language and the context of situation. As opposed to the rather normative literary expression which characterizes other works by this author, the language used in "Rosita, ate morrer" has marked signs of phonological, morphological, lexical and syntactic hybridity which, in postcolonial literature, is a powerful means to denounce and represent the (post-)colonial socio-cultural reality as well as a way to claim national identity. In Honwana's narration this reality is embodied in the persona of an illiterate young African woman who, 
in a mixture of Portuguese and Ronga, dictates to a man a two-page long letter addressed to the father of her daughter who has abandoned her for another woman and a better life as an assimilated worker in the Portuguese administration. The translation of this story into English by Richard Bartlett (for the same collection of African stories mentioned above) was done in collaboration with the author, Luís Bernardo Honwana. The co-authorial work process allows us to analyse the English version of the story as a case of mental model re-construction through translation which integrates the writer's opinions and goals, along with the translator's. It is relevant that the English translation of "Rosita, até morrer" is written in highly agrammatical language, mostly syntactically but to some extent also phonologically; it maintains as well all cases of African words with no glosses or explanation to fill in gaps in meaning, as in the original.

Some illustrative examples are offered by the following sentences from the very brief story. The first case reflects the influence of the phonological system of the national language Ronga on the phonological system of Portuguese, in a way that affects sibilants and aspects of nasality as well as the length of vowels and diphthongs.

(14) Eu não esquence mas eu já nem zanga nem nada.

(Honwana 1971/2001:172)

In the translation into English the decision to show the pidginization of the language has been to merely alter the syntax:

(15) I not forget but I still not angry or anything.

(Honwana 2000: 200)

But this is not the treatment given to all instances. For example in the translation in (16) the phonological structure of the English language has also been altered to somehow recover the pronunciation pattern of the original in Mozambican Portuguese as in (16): 
74 The Effect of Language and Context Variability

(16) Mulher çimilado quema os cabelo, veste çapato com vestida bonita.

(Honwana 1971/2001: 172)

Ssimilated woman burns the hair, puts shoes with beautiful dress.

(Honwana 2000: 200)

There are other cases which present different types of morphological distortion in the original, such as absence of gender or number and person agreement. These alterations have been kept in the translated version of the text as in the following pair of sentences:

(17) Sorita com Matilda com as outra manda os cumprimento também, elas está boa obrigado.

(Honwana 1971/2001: 172)

Sorita with Matilda with those other sends greeting too, she are good thankyou.

(Honwana 2000: 200)

(18) Os homem é maluco.

(Honwana 1971/2001: 172)

The mens is mad.

(Honwana, Luís Bernardo 2000: 200)

Maintaining pidginization and hibridity in the language of both the original and the translation is also done by keeping the lexical items from the national languages without footnotes, intratextual glosses or glossary to explain their meaning. This decision may result in a momentary silence, especially for the receiver of the translated text who is further apart from the original context of 
situation and culture. But as a countereffect the autochtonous words help to, quite unconsciously, build a mental model for the African world in which the story is set even if they are actually devoid of specific meaning. The following examples show how this operation works: The lexical items from Bantu languages open mental spaces for the Mozambican way of life even if the reader is not told that "lobolo" (19) refers to the dowry the bridegroom gives the bride's family, that "machamba" (20) is a labour field, "ucanhi" a kind of drink and "xingombela" a dance (21), or that "machimbomba" (22) is the Ronga name for bus:

(19) Elas faz pôco, eu sabe é assim quando mulher tem disgraça, sai uma filha e homem não faz lobolo.

(Honwana 1971/2001: 172)

They do littel, I know it is like that when a woman has disgrace, a child comes and the man doesn't make lobolo.

(Honwana 2000: 200)

(20) Eu fez machamba grande de milho com fijão com mandoinha, com mapila.

(Honwana 1971/2001: 172)

Made big machamba of mealie with beans with peanut, with mapila.

(Honwana 2000: 200)

(21) Beber ucanhi [...] dançar xingombela.

(Honwana 1971/2001: 173)

drink ucanhi $[. .$.$] dance the xingombela.$

(Honwana 2000: 200) 
76 The Effect of Language and Context Variability

(22) Quando vocé quer vir vocé escreve carta, da chófer de machimbomba de Olivera.

(Honwana 1971/2001: 173)

When you want to come you write letter, give the driver of Oliveira (sic) bus.

(Honwana 2000: 201)

The recourse to hybrid language in "Rosita, até morrer" is a literary sign of orality and an indicator of social marginality. In the translation, pidginizing the target language also performs these functions but has, besides, the overarching effect of instantiating the African world in the readers' minds, inviting them to construct a mental model which includes a direct reference to the multiethnic and plurilingual Mozambican reality. The maintenance in the translated text of the autochtonous words found in the original in Portuguese and the use of morphological, syntactic and phonemic structures which are divergent from the norm of the English language is a way to prime the writer's frame of mind and may be interpreted as a conscious attempt on the part of the co-authors of the translation (Bartlett and Honwana) to mentally approximate the foreign reader to the actual context of situation which is in fact the writer's context of creation.

\subsection{Priming the Translator's Mediating Perspective}

The third case that we will study is Margaret Jull Costa's translation of Crónica de Uma Travessia, a novel by Timorese writer Luís Cardoso, published in English with the name of The Crossing. In her version, Costa combines the presumable need for full understanding which might be expected from the Englishspeaking receiver with total respect for the plurilingual and bicultural 
model of the original, where the languages and practices of the Portuguese colonial heritage and the national essence of East Timor are naturally fused. Although the original text in Portuguese is fully conscious of the audience's prospective gaps of knowledge as concerns the presence of Tétum, Timor's vernacular language, and makes abundant use of footnotes to explain all terms and phrases, Costa chooses to limit the number of footnotes to a few cultural specifics and uses several other strategies to blend as much social, cultural and contextual information as possible in the language of the text. Her technique includes foreignizing the translation by keeping not only the Tétum words and expressions, but also by leaving legible traces of the Portuguese language and culture in the English text. Thus, she follows the so-called subversive strategies promoted in models of translation ethics (Berman 1984; Venuti 1995), and creates an extremely rich version of Cardoso's novel, both linguistically and culturally. The reader is thus unconsciously involved in the construction of a mental model based on the discourse dialogic polyphony which opens up different interacting mental spaces for the Timorese and Portuguese worlds within the narration in English. Through this indirect and subtle procedure, $\mathrm{s} /$ he is also invited to blend pre-existing cultural schemata with new knowledge and context functions. In cases such as this, the translator's position may be said to occupy a mediating space between the two worlds: the source and the target, as there is constant attention to the idiosyncratic universe of the original as well as a permanent wish to make it understandable to the recipient culture.

Elements from the quasi-divergent parameters applied to the translations of Couto's and Honwana's works coexist in Costa's translation of Crónica de Uma Travessia, in a way which makes it possible to stay faithful to Cardoso's text and goals without growing too distant from the receiver's interests and standpoint. A good example of the careful and conscientious treatment given to the 
fusion and function of languages and cultures in the translation is the following passage where Costa finds different ways to introduce in her text background information about social aspects of the Portuguese/Timorese culture(s). As can be seen below, in the original there are portions in Tétum which are then explained through footnotes, presumably thinking about the average Portuguese reader. In her translation, Costa not only keeps and explains the Tétum pieces, she also maintains bits of the Portuguese language making explicit the Portuguese world for the English speaking reader. This is Cardoso's text:

(23) Ele enchia o peito de ar para largar sopros pela garganta que saíam da sua boca como uma cascata, entoando o povo que lavas no rio. Imaginei então que teria de ser um rio do tamanho do mar e ainda não sabia que o Tejo entrava pela cidade dentro. E de tempos em tempos saíam da sua doca, jovens mais esbranquiçados que sumaúma, que o navio 'Timor' descarregava no cais de Díli e recolhia outros, [...] deixando em terra aquelas minhas conterrâneas abatidas de Loro Monu e Loro Sae, ${ }^{1}[. .$.$] vestidas à pressa de minissaia$ desajeitada, para irem ouvir o canto da sereia no cais:

- Malae bá ona!

${ }^{1}$ Loro Monu, pôr do Sol; Loro Sae, nascer do Sol.

${ }^{2} \mathrm{O}$ estrangeiro vai-se embora.

(Cardoso 1997: 91)

Numbers 1 and 2 in example (23) refer to the footnotes found in the Portuguese edition of Crónica de Uma Travessia, for the expressions in Tétum "Loro Monu", "Loro Sae" and "Malae bá ona". In Costa's translation, these expressions are included in the final glossary, but they are also accompanied by simple explanatory intratextual glosses juxtaposed to the Tétum words in the narration. Accordingly, "Loro Monu" becomes "Loro Monu in the west" and 
"Loro Sae" "Loro Sae in the east", while "Malae bá ona" is followed by its translation: "The foreigner is leaving" thus producing a double cognitive operation in the reader's mind which simultaneously creates a space for the other culture and fills it up with meaning. Furthermore, the reader is provided with other clues to help in his/her recreation of the textual reality. In this way the name of the fado "Povo que lavas no rio" is both kept in Portuguese and translated 'People of Portugal, you who wash in the river' to probably preserve its cultural identity. This is Costa's version of the passage:

(24) $[\mathrm{He}]$ used to fill his lungs with air and then release it in long exhalations, the words pouring from his mouth like a cascade-'Povo que lavas no rio', 'People of Portugal, you who wash in the river.' At the time, unaware that the Tagus flowed right through Lisbon, I thought that such a river would have to be the size of the sea.

From time to time, young men as pale as kapok would leave the Lisbon docks on the Timor and deposited on quayside at Díli, where the ship would pick up others, [...] leaving behind them my downcast female compatriots from both halves of the country - Loro Monu in the west and Loro Sae in the east - who had dressed hurriedly in awkward miniskirts, in order to hear the song of the siren on the quayside:

\section{Malae bá ona!}

The foreigner is leaving.

In the glossary:

Loro Monu-'where the sun sets'; used to described the western half of East Timor.

Loro Sae-'where the sun rises'; the eastern half of East Timor. 
Malae bá ona - 'the foreigner is leaving'.

(Cardoso 2000: 86-87)

The attempt to encourage the reader to build a mental space for the Portuguese culture is even clearer in the following fragment where universal fadist Amália Rodrigues, just “Amália" in Cardoso's original, is identified in Costa's translation as "the voice of fado". In the same way, "saudade", the Portuguese term for that vague feeling of desire or nostalgia, is transformed into "the sad, yearning face of fado" indirectly claiming the national-bound quality of this particular emotion. The term fado is then explained in the glossary.

(25) Na rádio ouvia-se Amália, até que ela um dia decidiu viajar até Timor e cantar para os Timorenses, que não puderam ver o rosto do fado nos momentos da dor e da saudade.

(Cardoso 1997: 90)

We had only ever heard Amália, the voice of fado, on the radio until one day she decided to come to Timor and sing to the Timorese people - not that we ever actually got a chance to see the sad, yearning face of fado.

In the glossary:

fado - a traditional Portuguese song form, usually full of yearning for what has been lost.

(Cardoso 2000: 86)

The same treatment is given to Timor's cultural aspects. In the original, footnotes are used for the Timor names or associations. In the translation, the Timorese expressions are kept to develop consciousness of the nation's history and identity, but they are also translated ad hoc to facilitate understanding, and fully explained in the glossary: 
(26) Era membro da UDT e defensor convicto do mate-banderahum. ${ }^{3}$ Como tal foi preso pela FRETILIN durante a guerra civil [...]

3 Expressão em tétum: morrer à sombra da bandeira (portuguesa).

(1997: 12, italics in the original)

He was a member of the UDT (Timorese Democratic Union) and a committed defender of mate-bandera-hum, a Tetum expression meaning 'to die in the shadow of the Portuguese flag'. As such, he was imprisoned by Fretilin (Revolutionary Front of Independent East Timor) during the civil war [...] In the glossary:

Fretilin - Revolutionary Front for an Independent East

Timor; in favour of a completely independent nation of East Timor.

mate-bandera-hum - literally, 'to die in the shadow of the Portuguese flag'; the slogan of the pro-Portuguese UDT. UDT - Timorese Democratic Union; in favour of retaining old colonial links with Portugal.

(Cardoso 2000: 2)

The effect achieved by Margaret Jull Costa in her work of translation is dialogical. She not only succeeds in offering the reader a solid representation of a multicultural and plurilingual society but does so in a way which makes it easy for the receiver to acquire new information from which different schemas of culture and behaviour may be developed with minimum effort. The type of translation chosen, where the autochthonous is kept and explained at the same time, maximizes relevance expectations and may be said to work appropriately both for the context of production and the context of reception. Costa's translation complies with the ethical demands formulated by Bhabha (1994), Spivak (1995), Berman (1984), 
Venuti (1995) or Bandia (2001), among many others, when they ask for a distinctive voice for postcolonial literatures in the Western world. It also achieves, we believe, Tymoczko's claim that "translation as a successful means of engagement and social change -like most political actions- requires affiliation and collective action." (2003: 201). The intensive effort made by Costa in her version of Crónica de Uma Travessia to preserve aspects of the Timorese and Portuguese languages and to involve readers in the socio-cultural symbols and identity of the represented reality is pervasive as it offers a means to introduce (or reactivate) elements from other worlds into the English cultural system surmounting the challenges of the targeted market. This model of translation primes flexibility and interface techniques and succeeds in creating interaction between the context of production, the context of reception and the social structures.

\section{Conclusion}

The analysis of the translations into English of the three postcolonial literary works in Portuguese has shown how variations in the choice of both language and context representations, especially as regards plurilingual features and cultural specifics, introduce key differences in the effects achieved by the target text. The three examples analysed have provided evidence of the translator's capacity to move within and between ideological positions; they have shown that the set of linguistic and context options chosen by each translator have an influence on the definition of his/her role as discourse interpreter, cultural negotiator, and re-creator of the textual reality. Thus, in the translations by Bartlett and Costa of Honwana's and Cardoso's works respectively, we have seen how maintaining the plurilingual quality of the text, with explicit references to their multicultural heritage, produces a hybrid effect 
which helps to approximate the foreign reader to the original context of situation. As opposed to this, a target-audience oriented perspective, as that encountered in Broockshaw's and Rafael's translations of Couto's stories, where monolingualism indirectly favours a nonspecific representation of the postcolonial world, introduces distance between the source and the recipient cultural systems.

Following the cognitive principles of mental model construction and relevance, we have focused on the linguistic strategies used by the three translators and on the cognitive representation or mental model which derives from the choices they make during the process of translation. We have also focused on the ideological stands that these choices represent as they seem to be directly related to the metacommunicative functions of identity reaffirmation and/or subversion carried by postcolonial texts. We have interpreted these choices in terms of relevance to the target audience (monolingualism and cultural equivalence), relevance to the source text (plurilingualism and/or hybrid language and preservation of cultural specifics) or relevance to dialogue (an in-between position favouring conscious cultural interaction through the alternation of plurilingualism and paraphrase, intratextual glossing, glossary making, and so on). In practical terms, we have shown that the translator's own model of the world interrelates with his/her attitude and feelings towards the translated text and its setting, the combination of both playing an active role not only in the selection of language but also in the representation of context.

\section{References}

Bandia, P. 2001. "Le concept bermanien de l' 'Etranger' dans le prisme de la traduction postcoloniale". En TTR 14.2, 123-139. Berman, A.1984. L'épreuve de l'étranger. Paris: Gallimard. Bhabha, K. 1994. The Location of Culture. London: Routledge. 
Cardoso, L. 1997. Crónica de Uma Travessia. A Época do Ai-DikFunam. Lisboa: D. Quixote.

Cardoso, L. 2001. The Crossing. London: Granta (M. Costa, trans.). Couto, M.1990. Cada Homem é uma Raça. Lisboa: Caminho.

----. 1994. Every Man is a Race (D. Brook-shaw, trans.). Oxford: Heinemann.

-----. 2000. "The Russian Princess". In E. Stephen (ed.), The Picador Book of African Stories (L. Rafael, trans.) 213-223. Oxford: Picador.

Garnham, A. 1987. Mental Models as Representations of Discourse and Text. New York: John Wiley \& Sons.

Honwana, B. 1971/2001. "Rosita, até morrer". In Saúte, Nelson (org.), As Mãos dos Pretos. Antologia do Conto Moçambicano 171-173. Lisboa: Dom Quixote.

----. 2000. "Rosita, until Death.” In Stephen Gray (ed.), The Picador Book of African Stories (R. Bartlett, trans.) 199-201. London: Picador.

-----. 1983. Mental Models. Cambridge, Mass: Harvard University Press.

-----. 1988. "How is Meaning Mentally Represented." In U. E. Santambrogio \& P. Violi (eds.) Meaning and Mental Representations 99-118. Bloomington, IN: Indiana U.P.

----. 1995. "Mental Models, Deductive Reasoning, and the Brain." In S. Gazzaniga (ed.), The Cognitive Neurosciences 999-1008. Cambridge, MA: MIT Press..

----. 2004. "The History of Mental Models." In K. Manktelow \& C. Chung (eds.), Psychology of Reasoning: Theoretical and Historical Perspectives 179-212. New York: Psychology Press.

Ku-Mesu, K. 1997. "Whose Relevance? Interpretation of Hybrid Texts by a Multiple Audience." Edinburgh Working Papers in Applied Linguistics 8, 44-53.

Spivak, C. 1995. "Translator's Preface" and "Translator's Note". In M. Devi(ed.), Imaginary Maps xxiii-xxxi. London: Routledge. 
Tymoczko, M. 2003. "Ideology and the Position of the Translator. In What Sense Is a Translator 'In Between'?" In M. Calzada (ed.), Apropos of Ideology 181-201. Manchester: St. Jerome.

van Dijk, A. 1989. "Discourse and Cognition in Society." In H. Giles \& R. Robinson (Eds.), Handbook of Social Psychology and Language 163-183. Chichester: Wiley.

Venuti, L. 1995. The Translator's Invisibility. London and New York: Routledge. 